\title{
Implementation of Water Debit Measurement Using Microcontroller-Connected Flow Meters
}

\author{
Juhriyansyah Dalle ${ }^{1}$, Muhammad Tamjidi ${ }^{1}$, Syarif Yusirwan Syafruddin ${ }^{2}$ \\ ${ }^{1}$ Department of Information Technolgy, Universitas Lambung Mangkurat, Jl. H. Hasan Basry, \\ Banjarmasin, Indonesia \\ ${ }^{2}$ Department of Information Technolgy, Universitas Cahaya Bangsa, Jl. A. Yani, Banjarmasin, Indonesia
}

\begin{abstract}
This research was conducted to measure water flow by implementing the Flow Meter tool. This was connected to a microcontroller and monitored through the website. In addition, the research was performed in stages, including (1) problem identification; (2) data collection; (3) hardware and software analysis, design, as well as website interfaces; (4) implementation and testing; and (5) concluding the development of hardware and software created. The results indicate the successful implementation of a water flow measurement prototype. This produced real-time data, updated every minute and displayed the required information on a website for direct monitoring. The study outcome is expected to be directly applied in dam or actual irrigation flow, and monitored on both website media and Android. Therefore, further research is required.
\end{abstract}

Keywords - irrigation channels, water discharge, microcontrollers, flow meters.

\section{Introduction}

Dams are buildings created to always be in contact with water.

DOI: 10.18421/TEM94-19

https://doi.org/10.18421/TEM94-19

Corresponding author: Juhriyansyah Dalle, Department of Information Technology, Universitas Lambung Mangkurat, Banjarmasin, Indonesia.

Email: j.dalle@ulm.ac.id

Received: 28 July 2020.

Revised: 27 October 2020.

Accepted: 04 November 2020.

Published: 27 November 2020.

(cc) BY-NC-ND (C) 2020 Juhriyansyah Dalle, Muhammad Tamjidi \& Syarif Yusirwan Syafruddin; published by UIKTEN. This work is licensed under the Creative Commons Attribution-NonCommercial-NoDerivs 4.0 License.

The article is published with Open Access at www.temjournal.com
These are small-scale structures used to raise water levels and ensure drainage through channels [1]. Moreover, several types are intended for certain purposes, based on the first function. These include the irrigation type projected for agricultural purposes, featuring the ability to flow river water to the designated area (land) through existing channels [2].

However, irrigation has not been efficiently and effectively used. The water application from irrigation is influenced by the farmers' age, education level, and knowledgeability [3]. Moreover, changes in weather and water resource availability also has an impact on water use and requirements in agricultural land [4]. The application of manual techniques involves a significant amount of plant irrigation time. This leads to ineffective water use, and farmers have to wait before turning off the water pump, and the lands are flushed one at a time. The manually controlled techniques are feasible in small and not for larger lands. Hence, there is need for technology to assist in water management as well as effectively and efficiently meet the farmers' requests [5]. Furthermore the conditions of water availability greatly influences agricultural success [6].

The lack of irrigation dams facilities has led to poor supervision and water flow monitoring. This challenge ought to be controlled in real-time, to ensure continuous supervision without a need for physical evaluation. In addition, the technology is also necessary for proper and more efficient performance of agricultural functions [7].

Moreover, there are several studies on the use of microcontrollers in connection with flow meters, and some used the Arduino Uno type. This was observed in a research performed by [8], with application in flow meters production. The fabricated device was efficiently used to measure transparent household water levels, based on the fuzzy logic method. In addition, the Uno Arduino microcontroller have a weakness in terms of the need to connect with a USB cable media. However, Wi-Fi media transmission is also possible through the Ethernet Shield remotely connected with a computer. This set up is used due to the absence of a Wi-Fi chip. In addition, some 
existing research showed the used of LED or SMS to display water discharge data only. This is different from the technology in this current investigation, where Wemos D1 microcontroller with a direct WiFi chip was used remotely without the need for cables and connections with other devices. Also, website-based research was adopted to monitor the water discharge data in real-time [9]. Therefore, the information obtained were recapitulated into a report for the needs of relevant agencies. The automation, online features and real time-based systems in today's digital era are a necessity in numerous ways [10].

Based on the description above, water for irrigation purposes is considered important. However, problems in terms of use efficiency and human related challenges (employees and manager) have been reported. These include the absence of tools or systems for direct monitoring of water discharges in agricultural irrigation dams. the aim of this study, therefore, is to evaluate water flow using a flow meter connected to the microcontroller. In addition, the resulting data is displayed with the Arduino IDE software, while the average is continuously shown on the website page. This technology is designed to easily identify the water discharge characteristics in real-time online. The output is to be further developed, on order to determine the water management policies for irrigation and ensure more effective and efficient application.

\section{Methodology}

The materials used in this study are based on survey results and on-site observations, including Water Flow. These research tools comprised of both hardware: Wemos D1, Flow Meter, Power bank, Jumper Cables, USB Cables, and Computer/laptop with a minimum specification of Dual Core and 2GB RAM, and software: PHP Programming Language, Arduino IDE, MySQL as a database, and Web browser. In addition, the research procedure include the stages to facilitate the result implementation as shown in figure 1 .

Figure 1. showed the several stages of the research procedure used. These were initated by identifying the problem through focusing, finding out, understanding, and knowing the boundaries of the research problem. In addition, the data collection process was performed by executing literature and field studies. The three stages of analysis and design concentrated on the hardware and software, as well as the website interfaces required.

This was followed by implementation and testing of hardware and software created, and the further evaluation of data generated. The final stage involved drawing conclusions and providing suggestions for further research development.
Moreover, table 1 shows some of the hardware components used in this research.

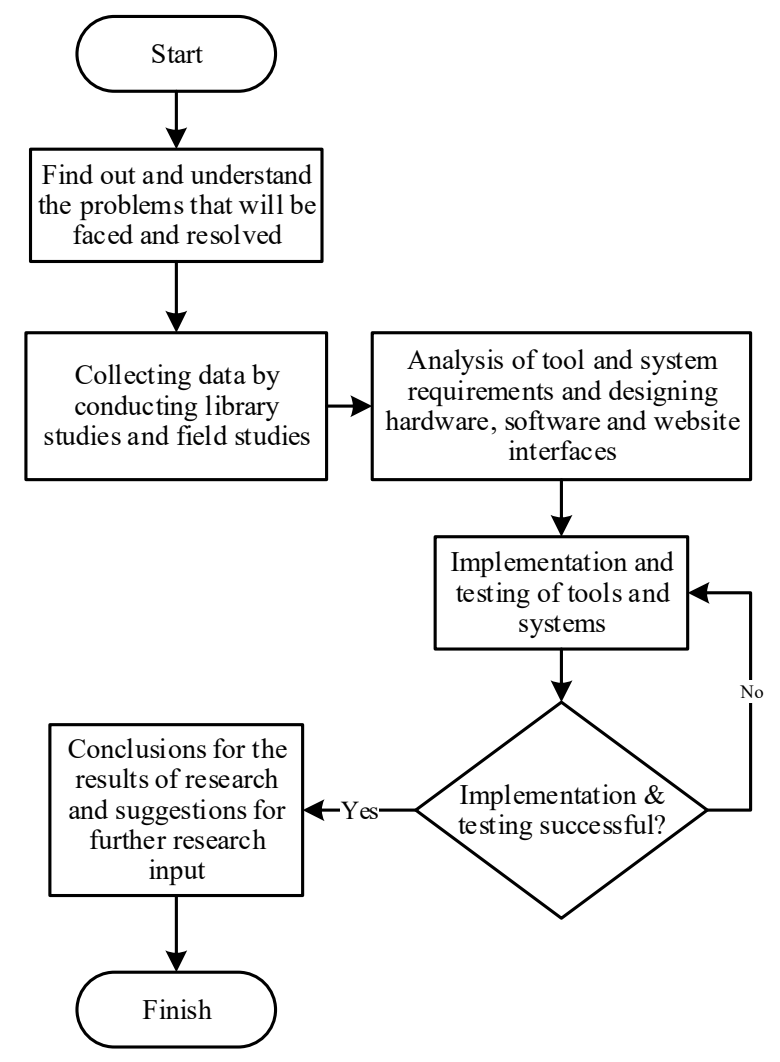

Figure 1. The stages of research

Table 1. Hardware device

\begin{tabular}{|c|l|c|}
\hline No & Component & Number \\
\hline 1 & Wemos D1 & 1 \\
\hline 2 & Flow Meter YF-S201 & 1 \\
\hline 3 & Battery 9V & 1 \\
\hline 4 & Jumper Cable & 10 \\
\hline 5 & Battery Connector 9V & 1 \\
\hline
\end{tabular}

\section{Results and Discussion}

\subsection{Flow Meters and Microcontrollers}

This section explains the water flow measurement obtained from the several prototype research stages using a flow meter connected to a microcontroller. The data generated show information related to flow meter name, and a $1 / 2$ inch variant was used.

This device is traversed by water, which facilitates the rotation on the rotor with a magnetic component, and subsequently produces a magnetic field. The flow meter possesses three cables, including the red and black ones used for $5 \mathrm{~V}$ and ground voltages, while yellow type is used for output. Therefore, the Wemos D1 microcontroller was used because of the inherent Wi-Fi chip, liberating the need to add an Ethernet Shield, as observed with the Arduino Uno type. This technology instigates the production of a more concise device. Furthermore, the flow meter 
and Wemos D1 microcontroller were assembled using jumper cables connected to the pins contained in the Arduino Uno. This unit was further fitted to connect with a sensor, where the D7 pin is attached with a gray colored jumper cable. In addition, the $5 \mathrm{~V}$ and GND pins were fitted with yellow and orange cables, respectively.

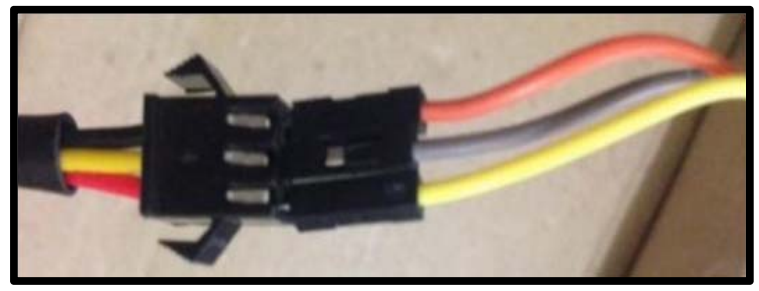

Figure 2. Flow meter cable and jumper cable

Figure 2. above shows the jumper cable inserted into a hole in the flow meter cable. The color used had no effect on anything, hence there was no need for to adjust the connecting color. However, the specific pin connected is regulated based on function, as observed in Figure 3. Therefore, the flow meter and Wemos D1 microcontroller were connected in a series of jumper cables based on the designated functions.

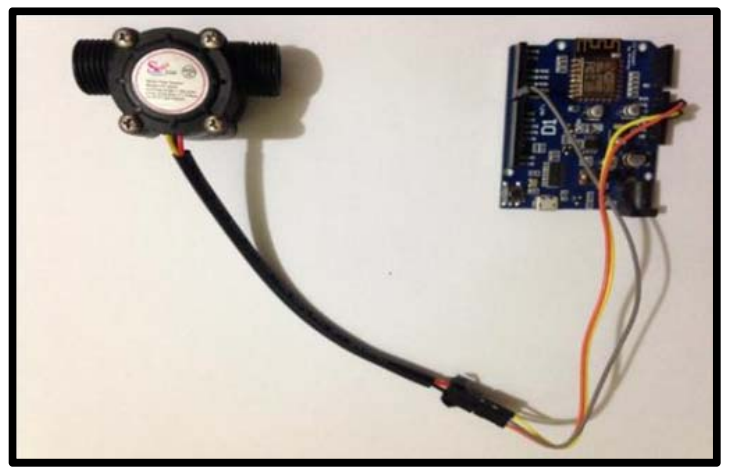

Figure 3. The prototype of water debit measurement

\subsection{Arduino IDE Application}

The script or program commands needed to measure water discharge with this application were uploaded to the Wemos D1 microcontroller hardware. Figures 4. and 5. shows an initial display of the Arduino IDE:

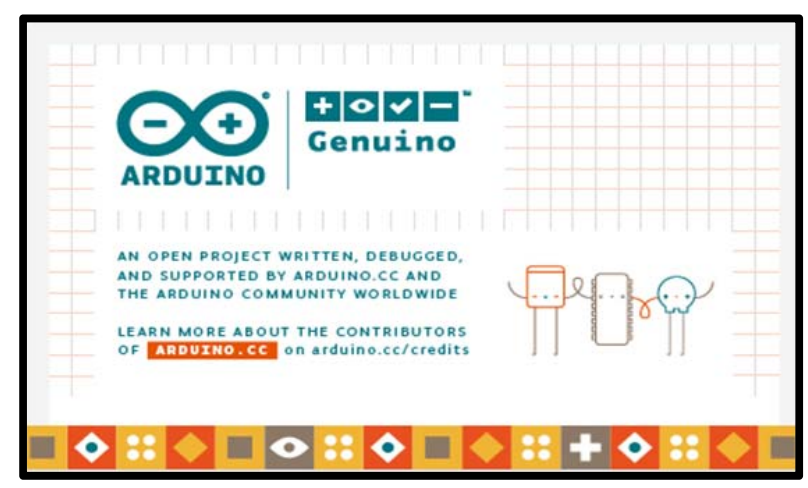

Figure 4. Display of the Arduino IDE loading process

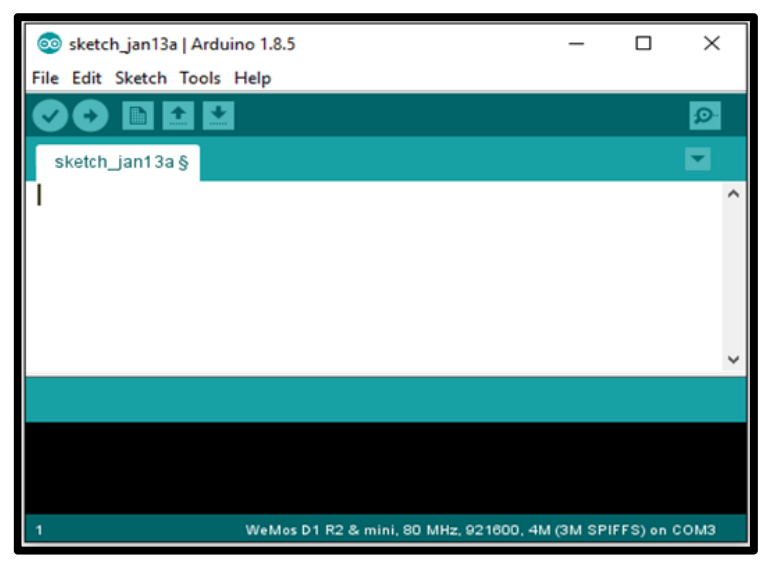

Figure 5. Initial display of Arduino IDE application

Figure 4. provides a display of the shelter while the application is run. This features the appearance of an Arduino IDE home page, before the script needed to measure water flow with the Wemos D1 microcontroller is entered. Therefore, the data is displayed on the website. This is one of the scripts used.

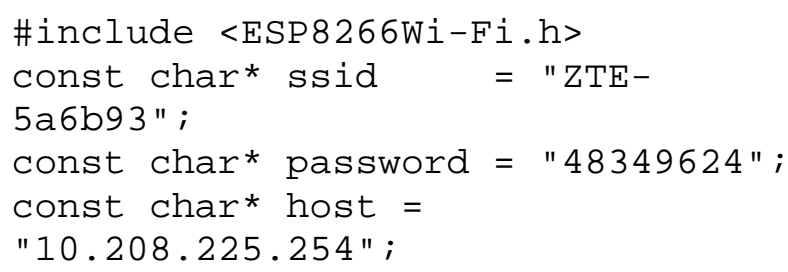

The script above is used to identify the Wi-Fi chip in Wemos D1 microcontroller as ESP8266. Meanwhile, SSID and password scripts were used to ensure a connection with the Wi-Fi network, for use during testing. In addition, the host script is used to connect the microcontroller with a laptop, and guarantee similarity in IP while connected.

The upload process into the Wemos D1 microcontroller is performed using the upload button contained in the Arduino IDE application after typing everything needed on the script page. In addition, the progress is displayed at the bottom, and the serial monitor displays the success or failure results after $100 \%$ completion by running the expected commands. Figures 6., 7., and 8. Below show the entire process.

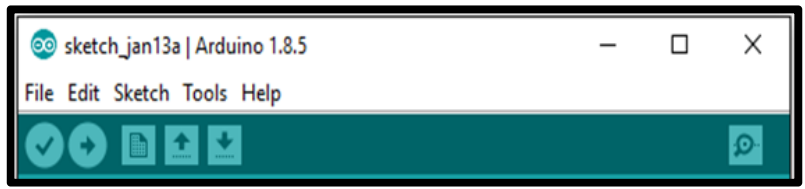

Figure 6. Upload button script

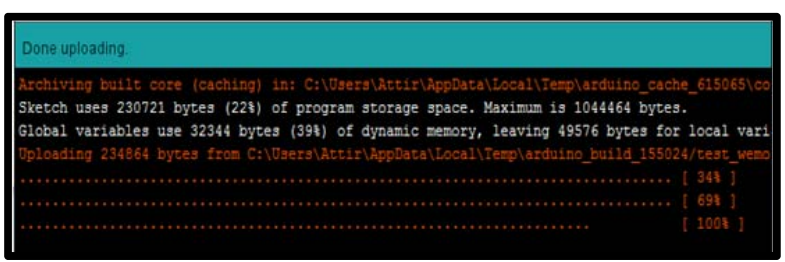

Figure 7. Upload process script 


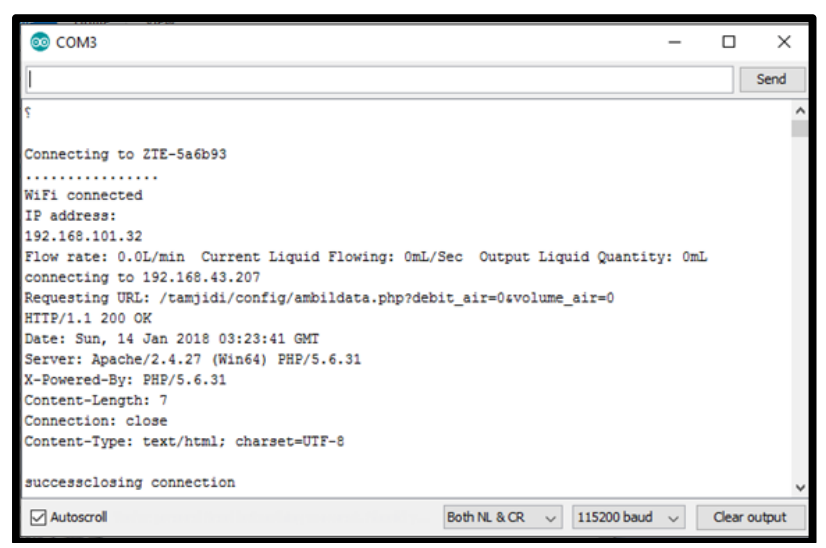

Figure 8. Uploaded results display script

\subsection{Website}

The Website showing the study result is characterized by several menus displaying pages with the requirements.

Furthermore, the dashboard menu page shows the latest results on discharge and water volume obtained in real-time. This also displays the graph of data averaged within 15 minutes, 1 hour and 24 hours, to ensure an accurate real-time monitoring.

This menu directly shows the pages with functions to display data generated from the measurement prototype in real-time. The information exhibited are based on water discharge and volume per second. Also, this page displays statistics on average water flow and volume within 24 hours, and arranged for one month, to be potentially printed and used as a monthly report.

The graphic menu displays a graph of water discharge within the last 5 minutes. This prototype subsequently enhances the visibility or monitoring of rise and fall in water generated, without needing the significantly large and available data sets.

\subsection{Testing Results}

This section showed the result of a prototype process of measuring real-time water discharge, displayed on the website using a flow meter connected to a microcontroller that has already been mentioned in this study. The two processes carried out were,

\subsubsection{Data Generator}

Data was generated by running a prototype of a water measurement using a flow meter connected to the microcontroller. The experiment was conducted three times using water as high as $10 \mathrm{~cm}, 15 \mathrm{~cm}$, and $20 \mathrm{~cm}$. The water in a container was connected to a $1 / 2 \mathrm{~cm}$ measuring pipe, in order to flow automatically through the meter that was mounted in the middle of the channel provided in Figure 9. as follows:

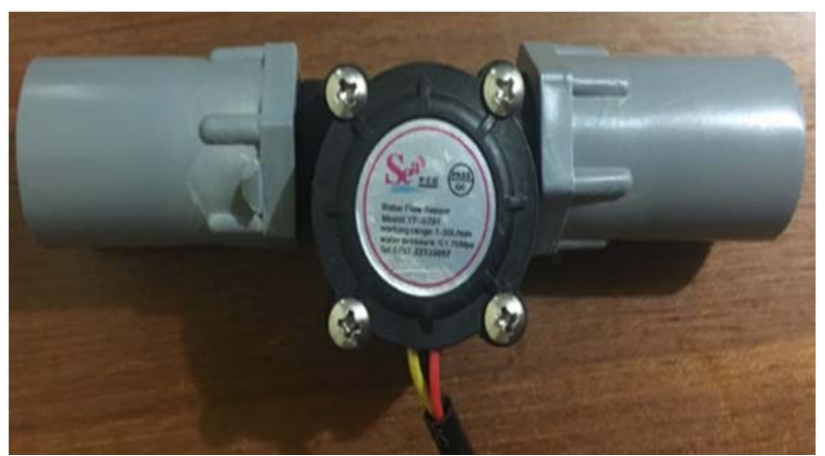

Figure 9. Pipe connected flow meter

The flow meter reacted and spinned on its inside called the rotor, then the resulting rotation was sent to the Dem wemos microcontroller which has been connected earlier, and has entered commands or settings made through the script in the Arduino application IDE. This command performed data processing through water that passes the flow meter, and produced a value in the form of debit and volume that was displayed on the website page. The flowing water was collected into the container that has been provided to measure water's height. The data generated and used in these experiments were the last five within the range of 5 mins, and those obtained from water as high as $10 \mathrm{~cm}, 15 \mathrm{~cm}$, and $20 \mathrm{~cm}$ were shown in the table below:

Table 2. $10 \mathrm{~cm}$ water height

\begin{tabular}{|c|c|c|c|}
\hline Data Date & Data Time & $\begin{array}{c}\text { Water } \\
\text { Discharge } \\
\text { (L/Min) }\end{array}$ & $\begin{array}{c}\text { Water } \\
\text { Volume } \\
\text { (ML) }\end{array}$ \\
\hline $17-01-2018$ & $22: 34: 26$ & 2 & 2 \\
\hline $17-01-2018$ & $22: 35: 26$ & 11 & 13 \\
\hline $17-01-2018$ & $22: 36: 26$ & 4 & 17 \\
\hline $17-01-2018$ & $22: 37: 26$ & 13 & 30 \\
\hline $17-01-2018$ & $22: 38: 26$ & 2 & 32 \\
\hline
\end{tabular}

Table $3.15 \mathrm{~cm}$ water height

\begin{tabular}{|c|c|c|c|}
\hline Data Date & Data Time & $\begin{array}{c}\text { Water } \\
\text { Discharge } \\
\text { (L/Min) }\end{array}$ & $\begin{array}{c}\text { Water } \\
\text { Volume } \\
\text { (ML) }\end{array}$ \\
\hline $17-01-2018$ & $21: 56: 35$ & 11 & 11 \\
\hline $17-01-2018$ & $21: 57: 35$ & 6 & 17 \\
\hline $17-01-2018$ & $21: 58: 35$ & 10 & 27 \\
\hline $17-01-2018$ & $21: 59: 35$ & 3 & 30 \\
\hline $17-01-2018$ & $22: 00: 35$ & 11 & 41 \\
\hline
\end{tabular}

Table $4.20 \mathrm{~cm}$ water height

\begin{tabular}{|c|c|c|c|}
\hline Data Date & Data Time & $\begin{array}{c}\text { Water } \\
\text { Discharge } \\
\text { (L/Min) }\end{array}$ & $\begin{array}{c}\text { Water } \\
\text { Volume } \\
(\text { ML) }\end{array}$ \\
\hline $17-01-2018$ & $22: 13: 40$ & 6 & 6 \\
\hline $17-01-2018$ & $22: 14: 40$ & 7 & 13 \\
\hline $17-01-2018$ & $22: 15: 40$ & 10 & 23 \\
\hline $17-01-2018$ & $22: 16: 40$ & 3 & 26 \\
\hline $17-01-2018$ & $22: 17: 40$ & 11 & 37 \\
\hline
\end{tabular}


From the experimental data above, the water discharge was able to change, due to the rotation that caused it to be fast or slow, and this process was monitored on the page provided on the website menu. The sketch prototype of the walking tool used during the trial of data income were shown in Figure 10. below:

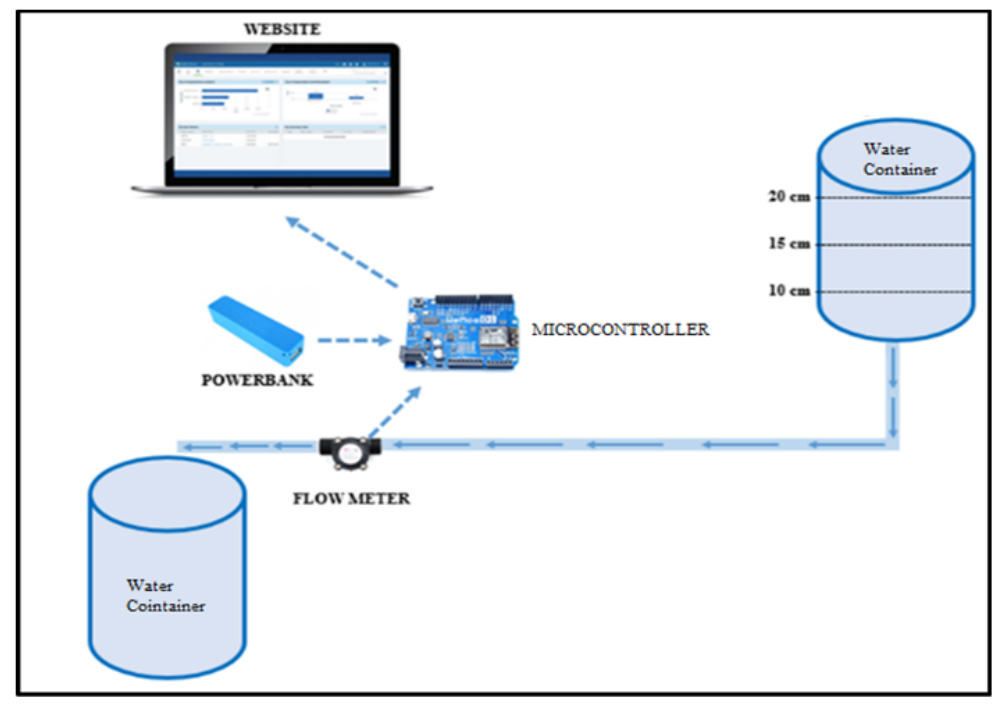

Figure 10. The prototype of Water Discharge Measurement Tool Prototype

\subsubsection{Data Processing}

Data processing was conducted using the website, and the information generated by the prototype of water flow measurements as high as $10 \mathrm{~cm}, 15 \mathrm{~cm}$, and $20 \mathrm{~cm}$ using a meter connected to the microcontroller, was sent and displayed on the website page in real-time. The data was then processed in the form of a graph displaying the average flow of water in 15 mins, 1 and 24 hours. However, in this trial, the time used was only 5 mins, and the last 5 data were collected from the 3 experiments conducted earlier. They were printed and made into a report, besides, the dashboard menu also displayed the latest data generated without the need to open the menu. Next, they were presented in the form of graphs, aimed to facilitate the monitoring of the rise and fall of the discharge and volume generated.

\subsubsection{Data Testing}

The data obtained after further testing was assessed using the Root Mean Square Error (RMSE) to evaluate performance in terms of conformity, the difference between the predicted and the true value, and determined the error rate generated by the measurement prototype of water discharge. The following table showed the differences in water levels before and after the trial:
Table 5. Water height before and after testing

\begin{tabular}{|c|c|}
\hline Before Testing & After Testing \\
\hline $10 \mathrm{~cm}$ & $7,2 \mathrm{~cm}$ \\
\hline $15 \mathrm{~cm}$ & $13,3 \mathrm{~cm}$ \\
\hline $20 \mathrm{~cm}$ & $18,2 \mathrm{~cm}$ \\
\hline
\end{tabular}

The following were results of the error calculations generated from the high water before and after the trial.

Water with $10 \mathrm{~cm}$ height:

$$
R M S E=\frac{10-7,2}{10}=0,28
$$

Water with $15 \mathrm{~cm}$ height:

$$
R M S E=\frac{15-13,3}{15}=0,11
$$

Water with $20 \mathrm{~cm}$ height:

$$
R M S E=\frac{20-18,2}{20}=0,09
$$

It was found that the higher the water being tested, the lesser error produced. Also, the higher the water available, the faster its pressure and flow, leaving small quantity in the pipe.

From the explanation above, this research has succeeded in implementing water flow measurements using a meter connected to the microcontroller. By using this system, water discharge was monitored online and in real-time. The data collected from this system was important for the efficient use of water, especially in agricultural irrigation. 
The efficient use of water for irrigation purposes is very important, because of its decreasing availability, and also increasing food needs due to the rise in population. As observed in California where the availability of groundwater ran low, due to prolonged drought and the use of water for excessive irrigation [11]. This was also supported by the previous research [12], which found that irrigation methods and water use rates affected crop yields.

Several efforts to increase the efficiency of water use for irrigation purposes have been carried out in several countries using an automatic regulation system and smart meters as implemented in this study. And also in India using smart meters in the distribution of water in small irrigation channels for agricultural purposes [13]. Therefore, this process is adjustable to the needs of the agricultural land diary. The regulation for the use of irrigation water developed by [14] comprehensive balance methodology involved carrying out a system diagnosis, making tactical plans, monitor water use, and improving asset management. Besides, the efficient use of water [15] through utilizing a sprinkler irrigation system for planting has been successfully carried out for rice cultivation in paddy fields. The development of an internet-based smart irrigation system with the use of the Arduino IDE software has also been implemented [16]. With this system, the use of water for agricultural land was streamlined, because watering was performed automatically only when plants need water, therefore, its use was very efficient. Besides, the use of Arduino IDE software has also been proven successful in creating an automatic water management system based on the Internet [17]. Moreover, it provided information in real-time and in the form of SMS to the system operator in the event of a decrease in water quality.

Water is a very important resource in human life and all living matters in the world. Most of the Earth $(70 \%)$ is water, and only a very small amount $(2.5 \%)$ is in the form of freshwater that is consumed by humans and other living matters, making it valuable and requiring high maintenance [18]. Its limitations also get worse, since an increase in population result to a rise in the need for clean water [19]. The increase is even expected to rise by $55 \%$ from 2000 to 2050 [20]. Besides, climatic change also affects the availability of water causing some regions to experience drought as observed in Vietnam [21].

Given the importance of freshwater for human life, its use needs to be regulated to ensure that it is more efficient and continues to be available not only for irrigation, and also for other purposes [22]. For this reason, the use of smart water technique with the latest information and communication technology (ICT) is needed to ensure that freshwater is used efficiently [23]. The use of information technology in the digital age is important in the realization of effectiveness and efficiency [24]. In the operation of smart technology in water management, it is also necessary to consider the use of electrical energy, which should be optimized for efficiency [25]. For example, the development of a water distribution system that flows to various regions, where each area is accountable for its uses, and the distribution is adjusted to the needs of the community, and leakages or other problems are easily detected [26].

For household use, some system for measuring and regulating the utilization of smart water using the internet have been developed in this study. Such as the smart and automatic management technology, developed for [27] measuring the use of water at the family level with high resolution. The use of smart water measurements, which provides the detailed and real-time feedback on the rate of use in each household motivate them to conserve it [28]. The smart meters for measuring the water needs in households based on season, weather, and equipment was also developed [29]. Similar research was also carried out [30] in the development of a system which measures, collects all data, and regulate the water use of each family more efficiently, and even its use between women and men, and in the toilet.

The efficient use of water needs to be carried out in different methods, in order to ensure the availability of fresh water for all life aspects. This effort should be undertaken in a collaborative manner involving all stakeholders, both from the government and the community, balanced with policies that prioritize the efficiency and effectiveness of water use. Therefore, with a good collaboration, supported by appropriate policies, this phenomena is realized.

\section{Conclusion and Future Research}

This research has successfully implemented the measurement of water discharge using a flow meter connected to a microcontroller that convey data online through website in real-time. The data generated in real-time was updated in $1 \mathrm{~min}$. The results of trials using water at a height of $10 \mathrm{~cm}, 15$ $\mathrm{cm}$, and $20 \mathrm{~cm}$ obtained an error of $0.28,0.11$, and 0.09 , respectively. This research is limited to the measurement of water discharge used in dams, and it is expected to be developed further for the implementation of smart management systems. With the creation and implementation of a smart system based on the internet which produces data online and in real-time, policies in managing water are better implemented for the efficiency efforts to be realized. For this reason, further development from this research is necessary. 


\section{References}

[1]. Harseno, E., \& Daryanto, E. (2008). Tinjauan Tinggi Tekanan Air di Bawah Bendung dengan Turap dan Tanpa Turap pada Tanah Berbutir Halus. Majalah Ilmiah UKRIM Edisi, 2.

[2]. Agustiawan, P., \& Utami, V. N. (2013). Perencanaaan bendung caringin di kecamatan cisolok kabupaten sukabumi provinsi jawa barat. Retrieved from: http://digilib.polban.ac.id/files/disk1/100/jbptppolbangdl-panjiagust-4960-1-daftar--2.pdf [accessed: 23 June 2020].

[3]. Pokhrel, B. K., Paudel, K. P., \& Segarra, E. (2018). Factors affecting the choice, intensity, and allocation of irrigation technologies by US Cotton farmers. Water, 10(6), 706. doi:10.3390/w10060706

[4]. Momvandi, A., Omidi Najafabadi, M., Hosseini, J. F., \& Lashgarara, F. (2018). The identification of factors affecting the use of pressurized irrigation systems by farmers in Iran. Water, 10(11), 1532. doi:10.3390/w10111532

[5]. Afrakhteh, H., Armand, M., \& Askari Bozayeh, F. (2015). Analysis of factors affecting adoption and application of sprinkler irrigation by farmers in Famenin County, Iran. International Journal of Agricultural Management and Development, 5(2), 8999. doi:10.5455/ijamd.158625.

[6]. Huang, Q., Xu, Y., Kovacs, K., \& West, G. (2017). Analysis of factors that influence the use of irrigation technologies and water management practices in Arkansas. Journal of Agricultural and Applied Economics, 49(2), 159-185. doi:10.1017/aae.2017.3

[7]. Azhari, A., \& Soeharwinto. (2015). Perancangan sistem informasi debit air. Singuda Ensikom, 13(36), 89-95.

[8]. Shrotriya, K., Jain, M., Mittal, M., Yadav, L., \& Vijay, N. (2017). Digital Water Meter Using Arduino. International Journal of Engineering and Management Research (IJEMR), 7(2), 276-279.

[9]. Utama, J. Y. (2016). Meteran Air Digial Berbasis Web Dengan Mikrokontroller Arduino UNO.

Retrieved from: http://repository.amikom.ac.id/files/Publikasi 09.11.2 788.pdf [accessed: 27 June 2020].

[10]. Hadi, S., Hamid, A., Mutalib, A. A., \& Dalle, J. (2018). Dilemma Between Applying Coherent Principle and Signaling Principles In Interactive Learning Media. The Open Psychology Journal, 11(1). doi:10.2174/1874350101811010235

[11]. Wilson, T. G., Kustas, W. P., Alfieri, J. G., Anderson, M. C., Gao, F., Prueger, J. H., ... \& Alstad, K. P. (2020). Relationships between soil water content, evapotranspiration, and irrigation measurements in a California drip-irrigated Pinot noir vineyard. Agricultural Water Management, 237, 106186.

https://doi.org/10.1016/j.agwat.2020.106186
[12]. Piri, H., \& Naserin, A. (2020). Effect of different levels of water, applied nitrogen and irrigation methods on yield, yield components and IWUE of onion. Scientia Horticulturae, 268, 109361. https://doi.org/10.1016/j.scienta.2020.1093

[13]. Riaz, W., Ahmad, Z., \& Muhammad, A. (2016). A smart metering approach towards measuring flows in small irrigation outlets. Procedia Engineering, 154, 236-242.

https://doi.org/10.1016/j.proeng.2016.07.459

[14]. Cunha, H., Loureiro, D., Sousa, G., Covas, D., \& Alegre, H. (2019). A comprehensive water balance methodology for collective irrigation systems. Agricultural Water Management, 223, 105660 .

https://doi.org/10.1016/j.agwat.2019.05.044

[15]. Pinto, M. A. B., Parfitt, J. M. B., Timm, L. C., Faria, L. C., Concenço, G., Stumpf, L., \& Nörenberg, B. G. (2020). Sprinkler irrigation in lowland rice: Crop yield and its components as a function of water availability in different phenological phases. Field Crops Research, 248, 107714. https://doi.org/10.1016/j.fcr.2020.107714

[16]. Thakur, D., Kumar, Y., \& Vijendra, S. (2020). Smart Irrigation and Intrusions Detection in Agricultural Fields Using IoT. Procedia Computer Science, 167, 154-162. https://doi.org/10.1016/j.procs.2020.03.193

[17]. Chowdury, M. S. U., Emran, T. B., Ghosh, S., Pathak, A., Alam, M. M., Absar, N., ... \& Hossain, M. S. (2019). IoT based real-time river water quality monitoring system. Procedia Computer Science, 155, 161-168. doi:10.1016/j.procs.2019.08.025

[18]. Adu-Manu, K. S., Tapparello, C., Heinzelman, W., Katsriku, F. A., \& Abdulai, J. D. (2017). Water quality monitoring using wireless sensor networks: Current trends and future research directions. ACM Transactions on Sensor Networks (TOSN), 13(1), 141. https://doi.org/10.1145/3005719

[19]. Lapworth, D. J., Nkhuwa, D. C. W., Okotto-Okotto, J., Pedley, S., Stuart, M. E., Tijani, M. N., \& Wright, J. J. H. J. (2017). Urban groundwater quality in subSaharan Africa: current status and implications for water security and public health. Hydrogeology Journal, 25(4), 1093-1116. doi:10.1007/s10040-016-1516-6

[20]. Ler, L. G. (2016). Analysis of current ICT solutions in water business processes. Procedia Engineering, 154, 3-10. https://doi.org/10.1016/j.proeng.2016.07.410

[21]. Chu, L., \& Grafton, R. Q. (2020). Water pricing and the value-add of irrigation water in Vietnam: Insights from a crop choice model fitted to a national household survey. Agricultural Water Management, 228, 105881.

https://doi.org/10.1016/j.agwat.2019.105881

[22]. Koech, R., Gyasi-Agyei, Y., \& Randall, T. (2018). The evolution of urban water metering and conservation in Australia. Flow Measurement and Instrumentation, 62, 19-26. https://doi.org/10.1016/j.flowmeasinst.2018.03.011 
[23]. Gourbesville, P. (2016). Key challenges for smart water. Procedia Engineering, 154, 11-18. https://doi.org/10.1016/j.proeng.2016.07.412

[24]. Dalle, J., Mutalib, A. A., Saad, A. L., Ayub, M. N., Wahab, A. W. A., \& Nasralla, A. M. H. (2015). Usability considerations make digital interactive book potential for inculcating interpersonal skills. Jurnal Teknologi, 77(29). doi:10.11113/jt.v77.6837

[25]. Castro-Gama, M. E., Pan, Q., Jonoski, A., \& Solomatine, D. (2016). A graph theoretical sectorization approach for energy reduction in water distribution networks. Procedia Engineering, 154, 1926. https://doi.org/10.1016/j.proeng.2016.07.414

[26]. Di Nardo, A., Di Natale, M., Gargano, R., Giudicianni, C., Greco, R., \& Santonastaso, G. F. (2018). Performance of partitioned water distribution networks under spatial-temporal variability of water demand. Environmental Modelling \& Software, 101, 128-136.

https://doi.org/10.1016/j.envsoft.2017.12.020
[27]. Nguyen, K. A., Stewart, R. A., Zhang, H., \& Jones, C. (2015). Intelligent autonomous system for residential water end use classification: Autoflow. Applied Soft Computing, 31, 118-131. https://doi.org/10.1016/j.asoc.2015.03.007

[28]. Liu, A., Giurco, D., \& Mukheibir, P. (2015). Motivating metrics for household water-use feedback. Resources, Conservation and Recycling, 103, 29-46. https://doi.org/10.1016/j.resconrec.2015.05.008

[29]. Pesantez, J. E., Berglund, E. Z., \& Kaza, N. (2020). Smart meters data for modeling and forecasting water demand at the user-level. Environmental Modelling \& Software, 125, 104633. https://doi.org/10.1016/j.envsoft.2020.104633

[30]. Nguyen, K. A., Stewart, R. A., Zhang, H., Sahin, O., \& Siriwardene, N. (2018). Re-engineering traditional urban water management practices with smart metering and informatics. Environmental Modelling \& Software, 101, 256-267. https://doi.org/10.1016/j.envsoft.2017.12.015 